\title{
Environmental assessment of risks associated with the Ordovician Dictyonema shale in the eastern part of the Baltic Klint
}

\author{
Sergey V.Lebedev ${ }^{1}$, Stanislav V.Dubrova ${ }^{1}$, Peter V. Fedorov ${ }^{1}$, \\ Vitaliy V. Kurilenko ${ }^{1}$, Willington Siabato ${ }^{2}$ \\ ${ }^{1}$ St.Petersburg State University, 7-9, Universitetskaya nab., St. Petersburg, 199034, Russian Federation \\ 2 Department of Geography, National University of Colombia, \\ Carrera 30 No. 45-03, 212, Bogota D. C., 111321, Colombia
}

For citation: Lebedev S. V., Dubrova S. V., Fedorov P.V., Kurilenko V.V., Siabato W. Environmental assessment of risks associated with the Ordovician Dictyonema shale in the eastern part of the Baltic Klint. Vestnik of Saint Petersburg University. Earth Sciences, 2018, vol. 63, issue 2, pp. 147-159. https://doi.org/10.21638/11701/spbu07.2018.202

\begin{abstract}
The results of research considered in this article made it possible to expand the understanding of the environmental risks associated with the highly radioactive bituminous argillites of the Baltic Sea region. The natural patterns of the distribution of natural radionuclides ${ }^{226} \mathrm{Ra},{ }^{232} \mathrm{Th}$ and ${ }^{40} \mathrm{~K}$ are established along the strike and thickness of layers. The average value of the effective specific activity (ESA) for all samples in the Koporka River valley amounted $1270 \mathrm{~Bq} / \mathrm{kg}$. The minimum value of ESA was $650 \mathrm{~Bq} / \mathrm{kg}$ (the closest to the seam roof level), and the maximum value was $3750 \mathrm{~Bq} / \mathrm{kg}$ (the second from the seam floor level). Conversion to mass fractions of natural radionuclides (NRN) showed that the average content of uranium in the sample amounted up to $90.7 \mathrm{~g} / \mathrm{t}$, thorium up to $11.4 \mathrm{~g} / \mathrm{t}$ and of potassium up to $4.1 \%$. The high heterogeneity of the content distribution of NRN along the strike of the Dictyonema shale seam was confirmed by studies of separate outcrops of highly radioactive rocks along the banks of the Tosna River. In general, the level of the argillites radioactivity has abnormally high value and exceeds the natural background more than ten times. The average annual values of the effective dose amounted from 5,8 to $10,7 \mathrm{mSv} /$ year, that should be classified as the territories of emergency ecological danger and zones of ecological disaster.
\end{abstract}

Keywords: Dictyonema shale, natural radionuclides, specific activity, potential radiation exposure, environmental risks.

\section{Introduction}

A geological formation with a high content of natural radionuclides (NRN) belongs to the category of natural geological objects defining the environment in the study area. There are two fundamentally different approaches to the assessment of the environmental risks associated with highly radioactive geological formations. One is the determination of NRN by considering the natural unevenness of their distribution along the strike, thickness of layers and calculating the radiation dose provided by the geological formation on the environment. Another way to estimate the environmental risk is a direct determination of the radiation dose to biota and humans by exploring the components of the envi-

(C) Санкт-Петербургский государственный университет, 2018 


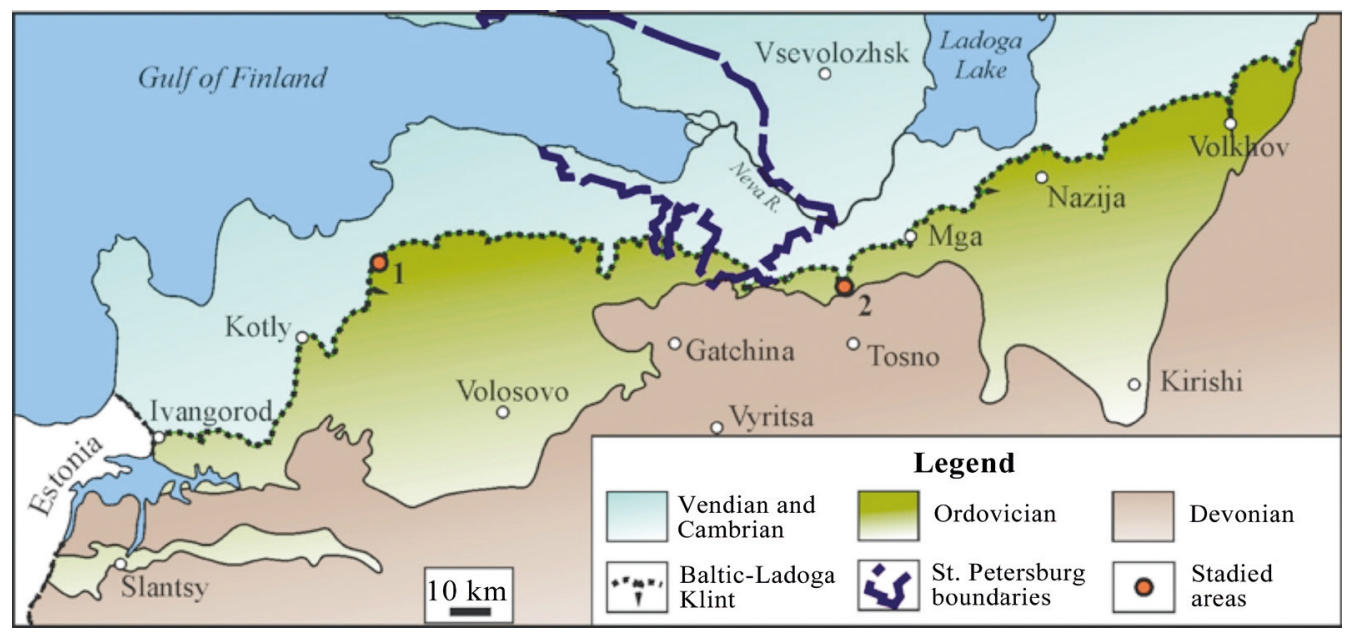

Fig. 1. Location of investigated objects: 1 - outcrops of bituminous mudstones in the Koporka River valley; 2 - submerged outcrops of bituminous mudstones with soil on them in the lower reaches of the Tosna River

ronment: the earth's surface, enclosed spaces, water and others (Murty and Karunakara, 2008; Isinkaye, 2008; Agbalagba and Onoja, 2011).

In this article, we have tried to significantly clarify the understanding of the environmental risks associated with the highly radioactive bituminous argillites of the Leningrad region based on the determination of NRN and the natural unevenness of their distribution along the strike and thickness of layers and to calculate the potential radiation exposure to the components of the environment.

\subsection{Geology of the investigation area}

A change in the thickness strata of radioactive bituminous argillites or bituminous mudstones, traditionally called the Dictyonema shale, occurs near the base of the Ordovician sedimentary sequence of the Leningrad region and reveals numerous rivers and streams cutting through the ledge of the eastern part of the Baltic Klint (the Ingrian (Ingermanland) Klint). To the south of the Klint the bituminous mudstones immerse under the carbonate rock strata composing the Ordovician plateau (Alexandrova, 1971).

Uranium-bearing bituminous mudstones with abundant remains of dendroid graptolites of the genuses Dictyonema - Rhabdinopora compose the upper part of the Pakerort sequence - the first level of the Ordovician Baltoscandia (Fig. 1). The informal name of strata comes from one of these genuses. In the international stratigraphic scale, the interval of the spread of argillites falls in middle time slice $\operatorname{Tr} 1$, i.e. in the middle of the lower Tremadocian (Cooper and Sadler, 2012).

In the local stratigraphic scheme of the Leningrad region, the Dictyonema shale separated as the upper subformation of the Kopor'e formation (Fig. 2) (Popov, et al., 1989). In the mudstone strata, the interlayers of quartz sandstones are marked, the number and thickness of which increases from top to bottom. Medium grained quartz sandstones with interbedded bituminous shale are attributed to the lower subformation of the Kopor'e for- 


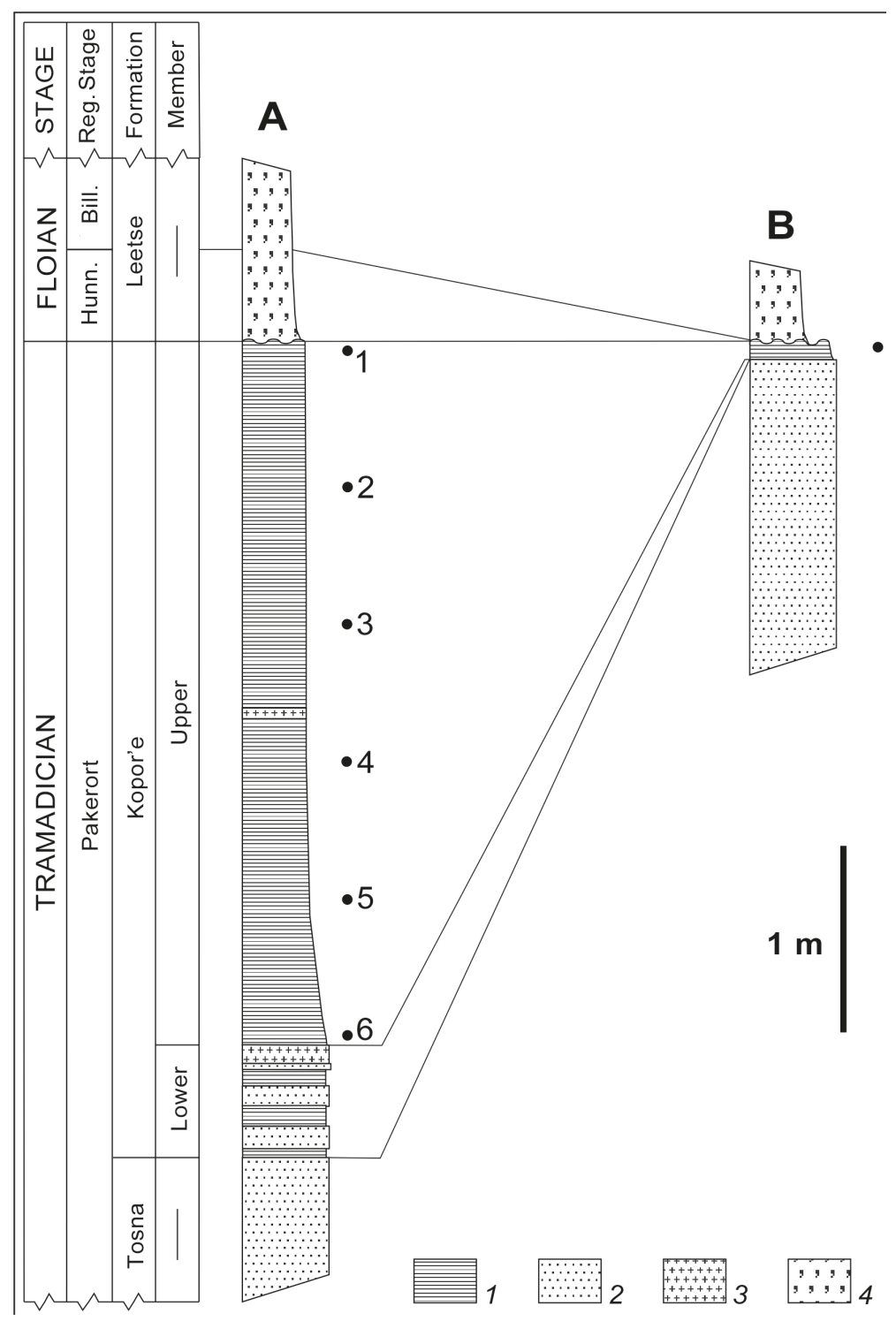

Fig. 2. Koporka (A), Tosna and Sablinka (B) cross-sections, simplified

Legend: 1 - bituminous shale; 2 - quartz sandstone; 3 - spiculite; 4 - glauconite sandstone.

Explanation of abbreviations: Reg. Stage $=$ Regional Stage; Hunn. $=$ Hunneberg; Bill. = Billingen

mation and mark a gradual transition from the underlying cross-bedded quartz sandstones of the Tosna formation to the mudstone strata of the upper subformation of the Kopor'e formation.

In the composition of bituminous mudstones is $85-90 \%$ of mineral and $10-15 \%$ of organic matter. The bulk of the rock is composed of a clay substance in the dispersed mixture with kolloalginit of cyanobacteria and zoo-chitin of graptolites (Balahonova, 2014). 
The thickness of the Kopor'e formation does not exist in the western part of the Leningrad region, in the area of the Klint between the cities Ivangorod and Kingisepp, to up to $5.5 \mathrm{~m}$ in some outcrops in the west of the pre-Klint band of the Leningrad region, and up to $6.7 \mathrm{~m}$ in some parts of the Klint under the cover of overlying deposits (Balahonova, 2014). Immersion of the entire Ordovician thickness in the south-southeast direction is about $2 \mathrm{~m} / \mathrm{km}$ on average (Zander and Salomon, 1971). To the west of Leningrad region, bituminous mudstones extend sublatitudinally in northern Estonia (the North Estonian Klint), occurring in a similar stratigraphic. Outcrops are confined to the line of the Baltic Klint (Hints, et al., 2014).

\section{Materials and methods}

The radioactivity of rocks and soil is determined by their content of NRN. The main $\mathrm{NRN}$ widespread in natural environment components are ${ }^{40} \mathrm{~K},{ }^{238} \mathrm{U}$, and ${ }^{232} \mathrm{Th}$.

The most accurate methods for the determination of the separate components of NRN in the natural environment (rocks, soil, groundwater, etc.) are the laboratory analysis methods for samples. As equipment, gamma scintillation or semiconductor spectrometers are usually used.

Selected field rock samples were dried and, if necessary, crushed to a fraction $<3 \mathrm{~mm}$. The specific activity of the samples was determined by gamma-ray spectrometry with a high-purity germanium (HPGe) detector RADEK in the laboratory of the Department of Radiation Hygiene, Center for Hygiene and Epidemiology of St. Petersburg. The spectrometer was calibrated in units of activity of radionuclides for exemplary measures of the activity of the radionuclides ${ }^{226} \mathrm{Ra},{ }^{232} \mathrm{Th}$ and ${ }^{40} \mathrm{~K}$. It should be noted that the spectral lines of uranium-containing rocks relate to ${ }^{214} \mathrm{Bi}(\mathrm{RaC})$, a decay product of $\mathrm{Ra}$. Therefore, gamma spectrometry in almost all versions determines only the equilibrium with radium (more $\mathrm{RaC}$ ), not the content of uranium.

The analysis calculated the effective specific activity of the rocks. The specific effective activity (ESA) of NRN is the total specific activity of NRN in the material determined by its biological impact on the human body and can be determined by the formula (NRB99/2009, 2009):

$$
\mathrm{ESA}=\mathrm{A}_{\mathrm{Ra}}+1,31 \mathrm{~A}_{\mathrm{Th}}+0,085 \mathrm{~A}_{\mathrm{K}},
$$

where $A_{R a}, A_{T h}$ and $A_{K}$ are the specific activity of radium, thorium and potassium respectively, Bq / kg.

We have researched and tested two outcrops of bituminous shale in the Russian part of the Baltic Klint (Ingrian Klint) in the area of their maximum (the Koporka River) and minimum (the Tosna River) thicknesses, as well as a small plot of the Tosna River valley, where, under the considered rocks, the soils evolved for several hundreds of years (Fig. 1).

In the Koporka River valley samples were selected from six levels of the cross-section of the Dictyonema shale with intervals of $0.7 \mathrm{~m}$. (Fig. 2A). From each level, four samples of shale were taken by using an iron cylindrical cup sampler with an inside diameter of $80 \mathrm{~mm}$ and a height $80 \mathrm{~mm}$; the distance between the horizontal profile was $0.7 \mathrm{~m}$. There were 24 selected samples. Lithologic features of the Dictyonema shale in the primary deposit allowed using a soil sampling methodology for the selection of fairly soft rock. Technically, the task was solved by forcing/hammering the cylindrical cup sampler into the 
rock. The weight of each dried sample was about $300 \mathrm{~g}$. The selection of sufficiently solid bedrock to determine the surface activity using the sampling techniques for loose rocks was produced for the first time.

As a mesure of the radioactivity of the territory was used the areal radionuclides activity $\left(\mathrm{Bq} / \mathrm{m}^{2}, \mathrm{Ci} / \mathrm{km}^{2}\right)$ which is defined as the radioactivity of a substance per 1 unit area.

For the evaluation of the potential radiation exposure from the gamma radiation of NRN in the distribution area of the Dictyonema shale we assessed the absorbed dose of radiation in the air from natural terrestrial and counted the specific activity of rocks $(\mathrm{Bq} / \mathrm{kg})$ in the value of the absorbed dose in the air as nGy per hour $(\mathrm{nGy} / \mathrm{h})$ by the coefficients adopted in the documents of the United Nations Scientific Committee on the Effects of Atomic Radiation (UNSCEAR..., 2000) and referring to the reports of the International Commission on Radiation Units and Measurements (ICRU..., 1994). The values of conversion coefficients for ${ }^{238} \mathrm{U},{ }^{232} \mathrm{Th}$ and ${ }^{40} \mathrm{~K}$ are $0.462,0.604$ and 0.0417 respectively.

As the direct measure of the radio-ecological situation, in the context of the present article, was adopted the equivalent dose rate in microsieverts per hour $(\mathrm{mSv} / \mathrm{h})$ and the dose in millisieverts, accumulated for a year (mSv/year). Knowing the content of certain radionuclides, the equivalent dose rate at $1 \mathrm{~m}$ from the surface layer was established and calculated by the formula (Belyaev et al., 2003):

$$
\mathrm{H}=(\mathrm{QU} \cdot 6,24+\mathrm{QTh} \cdot 2,78+\mathrm{QK} \cdot 14,4) \cdot 0,001,
$$

where $\mathrm{N}$ is the equivalent dose rate $\mathrm{mSv} / \mathrm{h}, \mathrm{QU}, \mathrm{QTh}$ of uranium and thorium, $\mathrm{g} / \mathrm{t}$, or $\mathrm{mg} / \mathrm{kg}$ (ppm), and QK is the potassium content, \%.

\section{Results and decisions}

\subsection{Determination of the specific activity of the Dictyonema shale in the cross-section along the Koporka River valley}

One of the objectives of the study was to identify a possible pattern in the distribution of NRN in the cross-section of the Dictyonema shale. Taking into account the previously identified heterogeneity of the distribution of NRN along the strike of the seam, for the better reliability of conclusions, we operated according to the averaged data for all four samples in each level. Results of the determination of ESA according to the analysis of samples are shown in Fig. 3.

The results of testing are as follows. The maximum value of the radioactivity of the rocks was recorded in the fifth horizon, closer to the bottom of the seam. The average value of ESA is calculated at $2360 \mathrm{~Bq} / \mathrm{kg}$. Approaching the seam roof, the effective specific activity regularly decreases and reaches a value of $680 \mathrm{~Bq} / \mathrm{kg}$.

According to the Radiation Safety Regulations (NRB-99/2009, 2009), as it approaches the top of the formation, the rock is gradually moves from environmental hazard category IV $(1500<\mathrm{ESA}<4000 \mathrm{~Bq} / \mathrm{kg})$ to environmental hazard category III $(740<\mathrm{ESA}<$ $1500 \mathrm{~Bq} / \mathrm{kg})$ and then to environmental hazard category II $(740<\mathrm{ESA}<370 \mathrm{~Bq} / \mathrm{kg})$. It should be noted that the main contribution to ESA is radium. It also determines the pattern described above, despite of the fact that the potassium content, on the contrary, increases from the bottom to the roof of the seam. 


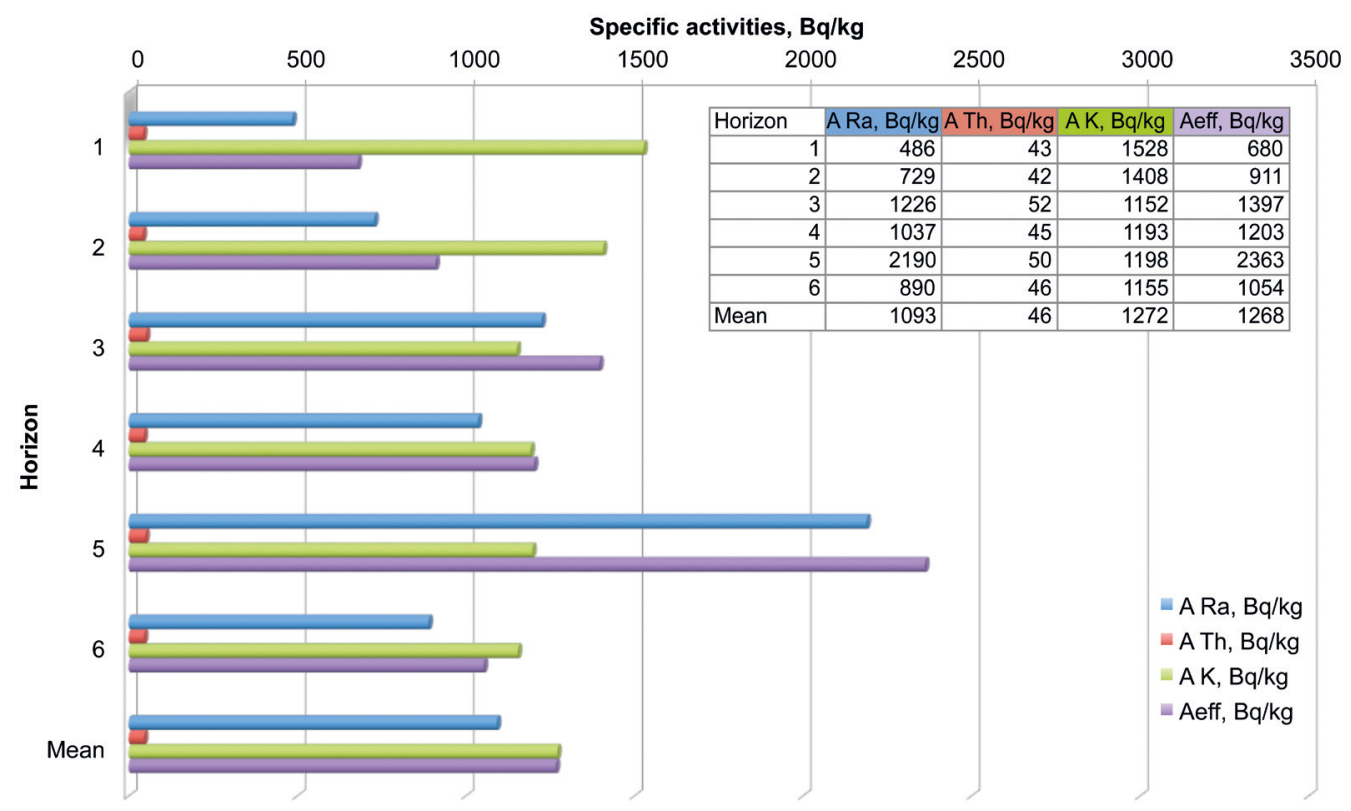

Fig. 3. The average values of the specific activity of the samples of tested levels

The average value of ESA for the 24 samples amounted $1270 \mathrm{~Bq} / \mathrm{kg}$. Conversion to mass fractions of NRN showed that the average content of uranium in the sample amounted up to $90.7 \mathrm{~g} / \mathrm{t}$, thorium up to $11.4 \mathrm{~g} / \mathrm{t}$ and of potassium up to $4.1 \%$. As we noted the regular change of ESA from level to level, it would be incorrect to use the standard deviation for the statistical evaluation of the uneven distribution of NRN for the entire sample selection. Here are the following parameters. The minimum value of ESA in some samples was $650 \mathrm{~Bq} / \mathrm{kg}$ (one level), and the maximum value was $3750 \mathrm{~Bq} / \mathrm{kg}$ (five levels). For the latter level, the range of values of activity was highest within the horizon, from 1190 to $3750 \mathrm{~Bq} / \mathrm{kg}$.

\subsection{The content of natural radionuclides and evaluation of the uneven distribution of the strike of the seam in the valleys of the Tosna and Sablinka Rivers}

This section discusses the results of the determination of the radioactivity of the Dictyonema shale. The Kopor'e formation is represented only by its upper subformation, having a minimum thickness of $12-15 \mathrm{~cm}$ (Fig. 2B). This small thickness of shale was observed in the outcrops of the valley of the Tosna River and its left tributary the Sablinka River at the intersection of these natural watercourses of the Baltic Klint.

At the testing range of the Sablinskaya Educational and Scientific Base of Saint-Petersburg State University, the Dictyonema shale were sampled in the outcrops "Roadside Quarry" (right side of the valley of the Tosna River) and "Sablinskiy Waterfall” (canyon of the Sablinka River). The sampling points within the outcrops were at a distance of 1-2 $\mathrm{m}$ from each other along the strike of the shale seam. The weight of each sample was about $500 \mathrm{~g}$. 


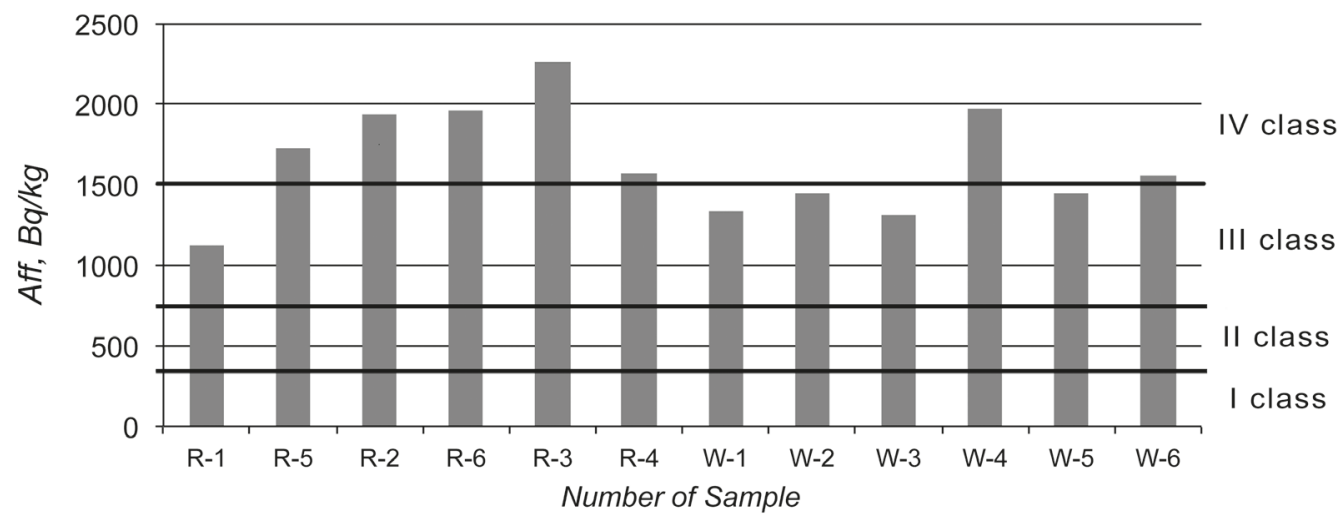

Fig. 4. Specific effective activity of samples. Letter "R" marked samples from "Roadside Quarry" outcrops. Letter "W" marked samples from "Sablinskiy Waterfall"

Determination results of the effective specific activity of the rocks according to the analysis of samples are shown in Fig. 4.

The effective specific activity of the bituminous shale amounted to an average of $1640 \pm 340 \mathrm{~Bq} / \mathrm{kg}$. According to the Radiation Safety Regulations (NRB-99/2009, 2009), for the value of natural radioactivity, these rocks belong to category IV of environmental hazards $(1500 \mathrm{~Bq} / \mathrm{kg}<$ ESA $<4000 \mathrm{~Bq} / \mathrm{kg})$.

The high heterogeneity of radionuclide distribution along the strike of the Dictyone$m a$ shale seam should be noted. So, in one outcrop, at a distance of $10 \mathrm{~m}$, the class of the environmental hazard of the material of the samples can vary from IV to III class and vice versa (Fig. 4). If we focus on the testing results of the two considered outcrops, the coefficient of variation is determined at $21 \%$.

The high heterogeneity of the content distribution of NRN along the strike of the Dictyonema shale seam was confirmed by additional studies of separate small outcrops of highly radioactive rocks along the banks of the Tosna and Sablinka Rivers (in total 13 outcrops). Thus, the results of the research are as follows. The value of ESA in some samples varies between 1270 and $2960 \mathrm{~Bq} / \mathrm{kg}$. On average, the radioactivity of mudstones was $2080 \pm 480 \mathrm{~Bq} / \mathrm{kg}$. On the whole, the tested rocks belong to categories III-IV of environmental hazards, in which ESA may range from $740-4000 \mathrm{~Bq} / \mathrm{kg}$. In a case of their use as construction materials, the requirements for safety from natural radiation sources should be considered.

Conversion to the mass fractions of uranium and thorium showed that the average content of uranium amounted to $150 \pm 40 \mathrm{~g} / \mathrm{t}$ and of thorium to $16 \pm 6 \mathrm{~g} / \mathrm{t}$ (the coefficient of variation is 26 and $35 \%$ respectively).

Thus, the exit site of shale exposed in the valleys of the Tosna and Sablinka Rivers, despite their small thickness, represent a specific radioecological danger.

\subsection{Areal activity of the Dictyonema shale in the Koporka River valley}

One measure of the radioactivity of the territory is the areal activity of radionuclides. In characterizing areal activity, it is necessary to specifically indicate what kind of radionuclide is in question. If, for example, it is reported that the specific activity of a rock or soil 
for thorium is $100 \mathrm{~Bq} / \mathrm{kg}$, this means that other elements (uranium, potassium, cesium, etc.) present in the rock or soil are not counted. Estimated indicators were designed with respect to long-lived technogenic radionuclides, such as ${ }^{137} \mathrm{Cs}$ and ${ }^{90} \mathrm{Sr}$, based on the practical levels of pollution areas.

Standards for the areal activity of natural radionuclides do not exist because, as a rule, a geological formation with a high content of NRN is covered by younger sediments, including quaternary sediments. Radioactive rocks are observed on the surface only in selected outcrops and do not extend for any significant distance.

Table 1 shows the surface activity of rocks for radium, thorium and potassium for all six levels of sampling in the outcrop of the Koporka River valley.

Table 1. Surface activity of samples

\begin{tabular}{|c|c|c|c|}
\hline Level & $\mathrm{Ra}, \mathrm{kBq} / \mathrm{m}^{2}$ & $\mathrm{Th}, \mathrm{kBq} / \mathrm{m}^{2}$ & $\mathrm{~K}, \mathrm{kBq} / \mathrm{m}^{2}$ \\
\hline 1 & 25.7 & 2.3 & 80.9 \\
\hline 2 & 38.1 & 2.2 & 73.6 \\
\hline 3 & 68.4 & 2.9 & 64.3 \\
\hline 4 & 55.0 & 2.3 & 62.8 \\
\hline 5 & 127.8 & 2.9 & 69.8 \\
\hline 6 & 45.7 & 2.3 & 57.6 \\
\hline Average & 60.1 & 2.5 & 68.2 \\
\hline
\end{tabular}

Areal indicators of radioactivity were put into practice by radioecological regulations after the accident at the Chernobyl Nuclear Power Plant for the assessment of the continuous contamination of large areas by technogenic radionuclide. In this article, we wanted to show a successful experience of using it as an additional assessment of the contamination of rocks by natural radionuclides.

\subsection{Evaluation of the potential radiation exposure from the gamma radiation of NRN in the distribution area of the Dictyonema shale}

As far as we know, the conversion coefficients of the specific activity for the absorbed dose in the air are calculated by the Monte-Carlo method for the photon emitters of natural radionuclides uniformly distributed in the soil (Saito and Jacob, 1995).

Research of (Saito and Jacob, 1995) is one of the most comprehensive studies of the relation of the absorbed dose in the air to a weight content of NRN uniformly distributed in the soil. There are other publications that are more precise, according to the authors, in terms of settlements and that obtained different results (Clouvas, et al., 2000; Gasser, et al., 2014). However, we will focus on the coefficients that appear in the reports of the International Commission.

Table 2 shows the calculated data for the absorbed dose in the air at a height of $1 \mathrm{~m}$ above the horizontal profile sampling in the outcrop of the valley of the Koporka River. 
Table 2. Absorbed doses of sampling horizons

\begin{tabular}{|c|c|c|c|c|}
\hline Level & Ra, nGy / h & Th, nGy / h & K, nGy / h & Total \\
\hline 1 & 225 & 26 & 64 & 314 \\
\hline 2 & 337 & 25 & 59 & 421 \\
\hline 3 & 567 & 31 & 48 & 646 \\
\hline 4 & 479 & 27 & 50 & 556 \\
\hline 5 & 1012 & 30 & 50 & 1092 \\
\hline 6 & 411 & 28 & 48 & 487 \\
\hline Average & 505 & 28 & 53 & 586 \\
\hline
\end{tabular}

The content of radioactive elements in the soil is derived from the rocks and the origin of soil. For example, higher levels of radiation are associated with magmatic rocks, such as granite.

There is a lot of research to determine the background level of radionuclides in soils in all regions of the world (Tzortzis and Tsertos, 2004; Lee, et al., 2009; Guidotti, et al., 2015). This, in turn, can be linked to the values of the absorbed dose in the air (UNSCEAR..., 2000). Specifically, the absorbed dose in the air determines the requirements for the radiation safety of the population in terms of external sources of gamma radiation from natural radionuclides.

These data can be compared with the values of the absorbed dose in the air above the ground in different countries. So, the absolute value of the average dose for Estonia is $59 \mathrm{nGy} / \mathrm{h}$ with a range of values from 14 to $230 \mathrm{nGy} / \mathrm{h}$. For Russia as a whole, the average absolute value of the dose rate is $65 \mathrm{nGy} / \mathrm{h}$, taking into account variations of values from 12 to $102 \mathrm{nGy} / \mathrm{h}$ (UNSCEAR..., 2000).

For the considered territory, Palaeozoic rocks with a high content of NRN are covered by overlaying deposits, including Quaternary deposits. However, there is a fairly extensive area along the Russian part of the Baltic Klint (Ingrian Klint) wherein shale come close to the surface. There, haloes of dispersion of NRN can be formed naturally by the mechanical or chemical enrichment of the soil with radioactive elements. In addition, at the present level of technological transformation of natural landscapes by humans, we cannot exclude the process of mixing non-radioactive and highly radioactive rocks, the result of which are man-made deposits, which occupy a relatively large area.

In the course of stripping radioactive rock in quarries to exploit any elements or in the construction of roads, buildings and structures on the surface, highly radioactive rocks are removed, dumps of which may take up a considerable area. Subsequently, contaminated soil can form on the surface of such local dumps, and plots may be get for residential development (Joshua, et al., 2009; Baykara, et al., 2011), as recently observed by the authors on the site of a farm quarry near the village of Kordelevo near the Izhora River in the Leningrad region.

To quantitatively evaluate the possibility of the accumulation of NRN in soils formed directly in the zone of contact with highly radioactive shale, the following experiment was performed. On the territory of the Sablinskiy Natural Monument near the confluence of the Sablinka and Tosna Rivers, two flows around outcrops have been formed as a result of 


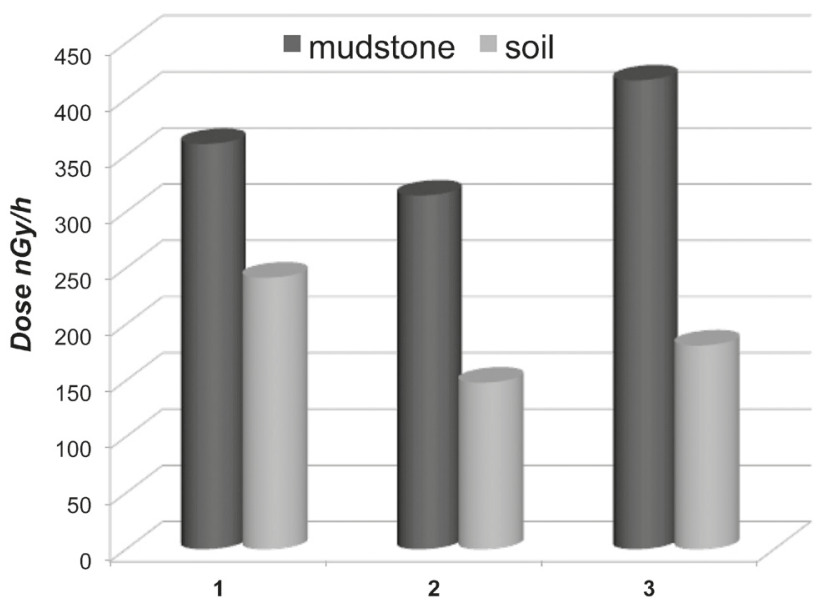

Fig. 5. Comparison of the dose of NRN in bituminous shale and soils

the meandering of the channel of the Tosna River a few hundred years ago. For the present study, this place is convenient because it is directly on the Palaeozoic basement rocks of different ages and compositions of soils formed on the bottom.

In the area of the "High outcrop" cross-section, we have selected three conjugate samples of indigenous bituminous shale and surrounding soil. The results of testing are shown in Fig. 5.

Comparison of doses of gamma radiation of NRN in the Dictyonema shale and soils shows that the radioactivity of the soil is at least $40 \%$ of the source rock $(67,47$ and 43 for samples 1, 2 and 3 respectively).

\subsection{Radioecological assessment of the living conditions of organisms}

With an average grade of uranium, thorium and potassium at $90.7 \mathrm{~g} / \mathrm{t}, 11.3 \mathrm{~g} / \mathrm{t}$ and $4.1 \%$ respectively, the value of the equivalent dose rate at $1 \mathrm{~m}$ from the surface layer was $0.66 \mathrm{mSv} / \mathrm{h}$. In a year $24 \cdot 365.25=8766 \mathrm{~h}$. Therefore, the created by NRN annual dose of shale can be up to $5.8 \mathrm{mSv} /$ year.

This value is obtained by averaging the entire data in the cross-section in one of the outcrops of the Dictyonema shale in the Koporka River valley. According to the results of sampling, higher values of NRN content are possible in particular layers. So, in horizon 5 , the content of uranium, thorium and potassium is $181.7 \mathrm{~g} / \mathrm{t}, 12.3 \mathrm{~g} / \mathrm{t}$ and $3.8 \%$ respectively. An annualized dose is $10.7 \mathrm{mSv} /$ year. Let us also recall the data from a study of radioactivity of shale in the area of the Sablinskiy Natural Monument where the average value of the content of NRN exceeds the average value in the Koporka River valley but is less than the maximum possible in the separate shale horizons.

According to the Basic Sanitary Rules of Radiation Safety (OSPORB-99/2010, 2010), territories within which the average annual values of the effective dose in the range of 5-10 mSv/year are territories of emergency ecological danger, and those of more than $10 \mathrm{mSv} /$ year are zones of ecological disaster.

This situation is most relevant for the gentle slopes of the Baltic Klint or the top of the Ordovician plateau in a strip a few hundred meters in width and $300 \mathrm{~km}$ in length along the Russian part of the limestone cliff (total area of about $150 \mathrm{~km}^{2}$ ). 


\section{Conclusions}

The research results enabled expanding the understanding of the environmental risks associated with the highly radioactive bituminous shales of the eastern part of the Baltic Klint and established the natural patterns of distribution of natural radionuclides (NRN) ${ }^{226} \mathrm{Ra},{ }^{232} \mathrm{Th}$ and ${ }^{40} \mathrm{~K}$ along the strike and thickness of the seam.

In general, the level of the bituminous shales radioactivity has abnormally high value (from 650 to $3750 \mathrm{~Bq} / \mathrm{kg}$ ) and exceeds the natural background more than 10 times. It was also found that the soil formed on the Dictyonema shale retains at least $40 \%$ of the radioactivity of the source rock for at least a few hundred years. Therefore, the soil may also be considered as a highly radioactive geological formation in the areas where the shale come close to the surface. The calculated data for the absorbed dose in the air at a height of $1 \mathrm{~m}$ above the horizontal profile sampling in the outcrop of the valley of the Koporka River, where the thickness of the shale amounted to $3.8 \mathrm{~m}$, shows that in sampling horizonts it ranges from 300 to $1100 \mathrm{nGy} / \mathrm{h}$ (on average $586 \mathrm{nGy} / \mathrm{h}$ ). This high values exceed the average absorbed dose for Estonia by 9,9 time and for Russia as a whole by 9 times.

With an average grade of uranium, thorium and potassium the created by NRN annual dose of shale can be up to $5.8 \mathrm{mSv} /$ year. That should be classified as a territory of emergency ecological danger. According to the results of sampling, higher values of NRN content are possible in particular layers. An annualized dose in horizon 5 is $10.7 \mathrm{mSv} /$ year that should be classifed as a zone of ecological disaster. This situation is most relevant for the gentle slopes of the Baltic Klint or the top of the Ordovician plateau in a strip a few hundred meters in width and 300 kilometres in length along the eastern part of the limestone cliff (total area of about $150 \mathrm{~km}^{2}$ ).

High values of the radiation level indicate that prolonged stay of people in the areas where the Dictyonema shale come close to the surface can lead to serious health problems. It is necessary to carefully monitor the radiation situation and inform the public that in the immediate vicinity of their place of residence there is a fairly strong source of natural ionizing radiation. Measures to reduce radiation exposure from natural radiation sources should be carried out for population groups exposed to radiation at doses exceeding $10 \mathrm{mSv} /$ year as a matter of priority. In the urban planning and functional zoning of territories, it is also necessary to take into account the influence of the geological environment which, as our studies have shown, can be quite significant.

Moreover, the results obtained also lead to new hypotheses in the field of paleogeoecology, namely, the possible effect of radiation on benthic biota. At the present time, this topic has not been studied in detail and could be the key to understanding the patterns of development of organisms in the Ordovician period.

\section{References}

Agbalagba, E. O., Onoja, R. A., 2011. Evaluation of natural radioactivity in soil, sediment and water samples of Niger Delta (Biseni) flood plain lakes, Nigeria. Journal of Environmental Radioactivity 103 (7), 667-671. doi: 10.1016/j.jenvrad.2011.03.002

Alexandrova, T.V., 1971. Fiziko-geograficheskoe opisanie i ekonomicheskaia kharakteristika [Geographical description and economic characteristics], in: Geologiia SSSR [Geology of the USSR] / Sidorenko, A. V., Selivanova, V. A., Kofman, V. S. (Eds.), Volume 1, Leningradskaia, Pskovskaia i Novgorodskaia oblasti [Leningrad, Pskov and Novgorod regions]. Nedra, Moscow, 26-38. (In Russian)

Balahonova, A.S., 2014. Renievoe orudenenie diktionemovykh slantsev Pribaltiiskogo basseina (Leningradskaia oblast') [Rhenium mineralization of the Dictyonema shale of the Baltic basin (Leningrad 
region)]. URL: http://earthpapers.net/renievoe-orudenenie-diktionemovyh-slantsev-pribaltiyskogo-basseyna (accessed 15.06.2018). (In Russian)

Baykara, O., Karatepe, S., Dogrub, M., 2011. Assessments of natural radioactivity and radiological hazards in construction materials used in Elazig, Turkey. Radiation Measurements 46 (1), 153-158. doi: 10.1016/j.radmeas.2010.08.010

Belyaev, A. M., Ivanyukovich, G. A., Kurilenko, V. V., Haykovich, I. M., 2003. Radioekogeologiia [Radioecology]: teaching aid. Publishing House of St. Petersburg University, St. Petersburg. (In Russian)

Clouvas, A., Xanthos, S., Antonopoulos-Domis, M., 2000. Monte Carlo calculation of dose rate conversion factors for external exposure to photon emitters in soil. Health Physics 78 (3), 295-302. doi: 10.1097/00004032-200003000-00007

Cooper, R. A., Sadler, P. M., 2012. The Ordovician Period, in: The Geologic Time Scale / Gradstein, F.M., Ogg, J. G. (Eds.). Elsevier, 489-524. doi: 10.1016/B978-0-444-59425-9.00020-2

Gasser, E., Nachab, A., Nourreddinea, A., Roya, Ch., Sellama, A., 2014. Update of 40K and 226Ra and 232Th series $\gamma$-to-dose conversion factors for soil. Journal of Environmental Radioactivity 138, 68-71. doi: 10.1016/j.jenvrad.2014.08.002

Guidotti, L., Carini, F., Rossi, R., Gatti, M., Cenci, R. M., Beone, G. M., 2015. Gamma-spectrometric measurement of radioactivity in agricultural soils of the Lombardia region, northern Italy. Journal of Environmental Radioactivity 142, 36-44. doi: 10.1016/j.jenvrad.2015.01.010

Hints R., Hade S., Soesoo A., Voolma M., 2014. Depositional framework of the East Baltic Tremadocian black shale revisited. GFF 136 (3), 464-482. doi: 10.1080/11035897.2013.866978

ICRU, International Commission on Radiation Units and Measurements, 1994. Gamma-ray spectrometry in the environment. Report 53. International Commission on Radiation Units and Measurements, Bethesda, Maryland.

Isinkaye, O. M., 2008. Radiometric assessment of natural radioactivity levels of bituminous soil in Agbabu, southwest Nigeria. Radiation Measurements 43 (1), 125-128. doi: 10.1016/j.radmeas.2007.11.005

Joshua, E. O., Ademola, J. A., Akpanowo, M. A., Oyebanjo, O. A., Olorode, D. O., 2009. Natural radionuclides and hazards of rock samples collected from Southeastern Nigeria. Radiation Measurements 44 (4), 401-404. doi: 10.1016/j.radmeas.2009.04.002

Lee, S. K., Wagiran, H., Ramli, A. T., Apriantoro, N. H., Wood, A. K., 2009. Radiological monitoring: terrestrial natural radionuclides in Kinta District, Perak, Malaysia. Journal of Environmental Radioactivity 100, 368-374. doi: 10.1016/j.jenvrad.2009.01.001

Murty, V.R. K., Karunakara, N., 2008. Natural radioactivity in the soil samples of Botswana. Radiation Measurements 43 (9-10), 1541-1545. doi: 10.1016/j.radmeas.2008.10.004

NRB-99/2009, Radiation Safety Regulations, 2009. Hygienic regulations and standarts (Sanitary rules and norms 2.6.1.2523-09/2009). Ministry of Healthcare of the Russian Federation, Moscow.

OSPORB-99/2010, Basic Sanitary Rules of Radiation Safety, 2010. (Sanitary Rules 1.2.6.1.2612-10). Ministry of Healthcare of the Russian Federation, Moscow.

Popov, L.E., Khazanovich, K. K., Borovko N. G., Sergeev, S. P., Sobolevskaya, R. F., 1989. Opornye razrezy i stratigrafiia kembro-ordovikskoi fosforitonosnoi obolovoi tolshchi na severo-zapade Russkoi platformy [The cross-sections and stratigraphy of Cambrian-Ordovician phosphorite obolus strata in the north-west of the Russian platform]. Nauka, Leningrad. (In Russian)

Saito, K., Jacob, P., 1995. Gamma ray fields in the air due to sources in the ground. Radiation Protection Dosimetry 58 (1), 29-45.

Tzortzis, M., Tsertos, H., 2004. Determination of thorium, uranium and potassium elemental concentrations in surface soils in Cyprus. Journal of Environmental Radioactivity 77, 325-328. doi: 10.1016/j. jenvrad.2004.03.014

UNSCEAR, United Nations Scientific Committee on the Effects of Atomic Radiation, 2000. Report to the General Assembly, with scientific annexes. Volume I: Sources, Annex B: Exposures from natural radiation sources. United Nations Publications, New York.

Zander, V.N., Salomon, A.P., 1971. Tectonics, in: Geology of the USSR. Volume 1. Leningrad, Pskov and Novgorod regions / Sidorenko, A. V., Selivanova, V. A., Kofman, V. S. (Eds.), Nedra, Moscow, 361-406. (In Russian) 
Author's information:

Sergej V.Lebedev - sergey-lebedev1950@yandex.ru

Stanislav V.Dubrova - dubrova.stanislav@gmail.com

PetrV.Fedorov - ordovician@yandex.ru

VitalijV.Kurilenko — vvk_eco@mail.ru

WillingtonSiabato — wlsiabatov@unal.edu.co

\title{
Геоэкологическая оценка рисков, связанных с ордовикскими диктионемовыми сланцами в восточной части Балтийского глинта
}

\author{
С. В. Лебедев ${ }^{1}$, С. В. Дуброва ${ }^{1}$, П. В. Федоров ${ }^{1}$, В. В. Куриленко ${ }^{1}$, В. Сиабато \\ ${ }^{1}$ Санкт-Петербургский государственный университет, \\ Российская Федерация, 199034, Санкт-Петербург, Университетская наб., 7-9 \\ 2 Department of Geography, National University of Colombia, \\ Carrera 30 No. 45-03, 212, Bogota D. C., 111321, Colombia
}

Для цитирования: Lebedev S. V., Dubrova S. V., Fedorov P. V., Kurilenko V.V., Siabato W. Environmental assessment of risks associated with the Ordovician Dictyonema shale in the eastern part of the Baltic Klint // Вестник Санкт-Петербургского университета. Науки о Земле. 2018. Т. 63. Вып. 2. C. 147-159. https://doi.org/10.21638/11701/spbu07.2018.202

Результаты представленных в этой статье исследований позволили расширить понимание экологических рисков, связанных с высокорадиоактивными диктионемовыми сланцами Балтийско-Ладожского уступа. Природные закономерности распределения радионуклидов ${ }^{226} \mathrm{Ra},{ }^{232} \mathrm{Th}$ и ${ }^{40} \mathrm{~K}$ определялись по простиранию и мощности пласта сланцев. Среднее значение эффективной удельной активности ( $\left.\mathrm{A}_{э}\right)$ для всех образцов в долине р. Копорки составило 1270 Бк/кг. Минимальное значение Аэф равнялось 650 Бк/кг (ближайший слой к кровле пласта), а максимальное значение оценивалось значением 3750 Бк/кг (второй слой от подошвы пласта). Пересчет в массовые доли природных радионуклидов (ПРН) показал, что среднее содержание урана в образцах составило до 90,7 г/т, тория - до 11,4 г/т и калия - до 4,1\%. Высокая неоднородность распределения содержания ПРН по простиранию пласта диктионемовых сланцев была подтверждена исследованиями отдельных выходов высокорадиоактивных пород вдоль берегов р. Тосны. В целом уровень радиоактивности сланцев аномален и превышает естественный фон более чем в 10 раз. Среднегодовые значения эффективной дозы составили от 5,8 до 10,7 м3в/год, т.е. местность, где они наблюдаются, следует классифицировать как территорию чрезвычайной экологической опасности и зону экологического бедствия.

Ключевые слова: диктионемовые сланцы, природные радионуклиды, эффективная удельная активность, потенциальное радиационное облучение, экологические риски.

Контактная информация:

Лебедев Сергей Васильевич - sergey-lebedev1950@yandex.ru

Дуброва Станислав Викторович - dubrova.stanislav@gmail.com

Федоров Петр Владимирович — ordovician@yandex.ru

Куриленко Виталий Владимирович — vvk_eco@mail.ru

Сиабато Виллингтон - wlsiabatov@unal.edu.co 